\title{
Storytelling desde la tierra para salvar la tierra
}

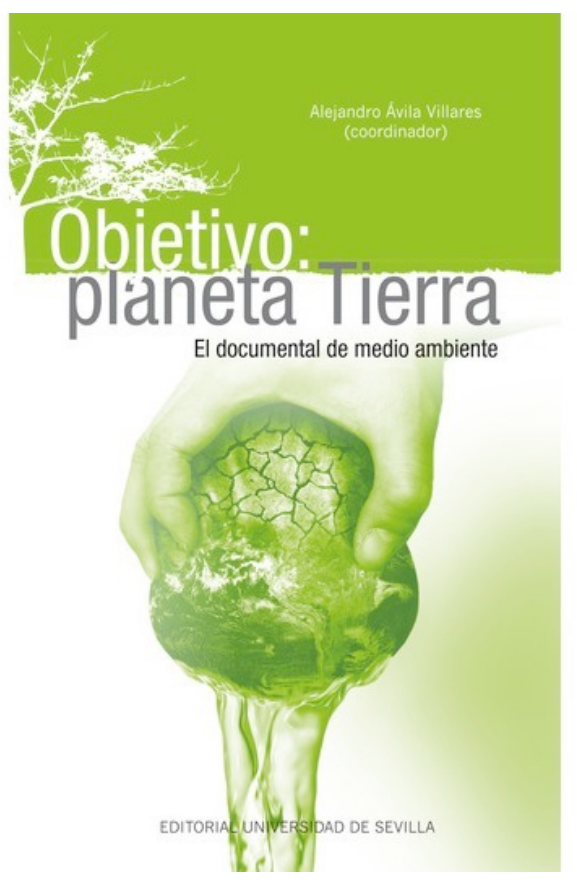

DOI: http://dx.doi.org/10.12795/Ambitos.2019.i45.19

\section{Objetivo: planeta Tierra}

Alejandro Ávila (Coord).

Editorial Universidad de Sevilla, España, 2018.

246 páginas

Reseña por Daniel Rodrigo-Cano

"Estamos en un período de gracias, tenemos tiempo -quizá una generaciónpara salvar al medio ambiente de los efectos finales que ya hemos causado".

Barry Commoner, 1970 
El director de cine Raúl Beceyro dice que "el cine documental no es un género. El film documental cuenta hechos que han sucedido o que están sucediendo independientemente de que con ellos se haga o no una película. Sus personajes existen también fuera del film, antes y después del film". Pero el periodista Alejandro Ávila cuestiona estas afirmaciones a través de es este libro en el que coordina a otros ocho autores.

Esta obra coral recoge entre sus páginas más de un centenar de documentales que obligan al lector a replantearse temas que afectan a todas y todos por su relevancia y por su urgencia, como la biodiversidad, el cambio climático, la contaminación, la extinción de especies o la sobreexplotación. Mientras las cámaras del cine han puesto imagen a la naturaleza el cine documental del medio ambiente ha puesto rostro a la realidad sin confundir la realidad con la manipulación inherente al proceso comunicativo. Especialmente relevante en tiempos de falsas noticias se valora el cine documental coherente, verdadero y honesto.

Alejandro Ávila se rodea en este libro periodistas, cineastas, críticos, analistas... como Pamela Biénzobas, Martín Cuesta, Mónica Delgado, Víctor Esquirol y Blanca Martínez para recoger desde el legado de Félix Rodríguez de la Fuente en la defensa de la biodiversidad hasta riesgos más actuales como la contaminación y el cambio climático sin perder de vista la observación y el conocimiento de la naturaleza para convertirlo en una crítica al patriarcado desde un paradigma necesario ecofeminista.

Los autores, profesionales relacionados con el cine documental conocen bien el trabajo social y ambiental y las relaciones con movimientos ecologistas e insinúan la necesidad de más trabajo común entre el cine, el ecologismo y la ciencia con la intención de dar a conocer con más solidez la unión entre el ser humano y el entorno natural, para ello los autores van desgajando los problemas ambientales que están generando graves problemas sociales desde el cine documental.

La obra mantiene una estructura similar a la evolución que han llevado el cine documental sobre la naturaleza, así en dos primeros capítulos se hace referencia a los documentales de vida animal, para pasar al capítulo sobre la biodiversidad y sus amenazas, y continuar con otros tres capítulos que exponen el deterioro del medio ambiente como la contaminación, la sobreexplotación y el cambio climático. Pero la coordinación de la obra deja para el final un capítulo abierto a la esperanza y la acción desde el ecofeminismo en el que pone voz a las luchas de mujeres por el bien común frente a las amenazas ambientales y cómo se han recogido en el cine documental.

Tiene a bien Ávila cerrar este libro con una recopilación de la filmografía citada en el texto, prácticamente 110 documentales recopilados y en el que aquí se hecha en falta las 
posibilidades que ofrece lo digital para tener recopilados enlaces a esta ventana abierta al cine documental que nos abren los autores.

Este texto aporta al lector un recorrido histórico por el cine documental, desde las primeras imágenes de la ejecución de la elefanta Topsy por los estudios Edison hasta el cine documental actual de la mano de Ricardo Gamaza y Trileros del agua. Pero este recorrido hay que detenerlo en la puesta en valor que los autores realizan por el cine documental actual andaluz, con directores andaluces o que recogen la realidad ambiental de Andalucía, como Guadalquivir de Gutiérrez Acha, pero también "desfilan" Arturo Menor, Gerardo Olivares, Manuel $\mathrm{H}$. Martín y La vida en llamas para retratar la vida de los compañeros de INFOCA, Manu Trillo, Jorge Molina, Fernando Arroyo o Ricardo Gamaza.

La obra coordinada por Alejandro Ávila más allá de la excelente recopilación de documentales como se ha comentado es un valioso recurso para la comunicación pero también para la educación en general y la educación ambiental en particular, dado que el cine de ficción puede ser una herramienta eficiente de sensibilización y movilización social, en la que la educomunicación tiene que estar presente. 